\title{
Population Density Regulation in Clethrionomys: the Effect of Changing Litter Size and Length of Reproductive Season
}

\author{
Nils Chr. STENSETH \& Torbjörn FAGERSTRÖM
}

\begin{abstract}
Stenseth, N. C. \& Fagerström, T., 1986: Population density regulation in Clethrionomys: the effect of changing litter size and length of reproductive season. Acta theriol., 31, 27: 367-384 [With 4 Tables \& 4 Figs.]

A model developed for studying the population dynamic consequences of female territoriality (as seen in Clethrionomys populations) is analyzed. Specifically we investigate the plausibility of Bujalska's (1970) hypothesis for explaining the stability of the central European populations of C. glareolus, and the rore of Wiger's (1982) hypothesis for explaining the cyclicity of the more northern populations of C. glareolus. It is argued that these hypotheses essentially are the same, in the sense that they represent the same theory in different parts of parameter space. In areas with long summers and relatively small litters, the exclusive territoriality of females is always found to produce stable population dynamics (i.e., Bujalska's idea is supported); however, in areas with short summers and relatively large litters, the exclusive territoriality of females is found to produce non-stable, cyclic, population dynamics (a necessary feature for Wiger's idea to be plausible). We have, however, been unable to generate a typical microtine cycle: obviously additional factors are needed in order to mold the basic cycles generated by the model into dynamics that are in quantitative agreement with that of real popolation.

[Dept. of Biol., Division of Zool., Univ. of Oslo, P.O.Box 1050, Blindern, N-0316 Oslo 3, Norway; and Dept. of Zool., Univ. of Uppsala, P.O.Box 561, S-751 22 Uppsala, Sweden].
\end{abstract}

\section{INTRODUCTION}

Cyclic density changes in microtines (voles and lemmings) have long been considered a mystery (e.g., Elton, 1942; Krebs, 1978, 1979; Stenseth, 1985a). Unfortunately, we still do not know why they occur in so many microtine rodents species (e.g., Krebs and Myers, 1974, Stenseth, 1985a) whereas they only rarely (or never) occur in other species. In particular, we do not understand why some species are cyclic in parts of their range of distribution but stable in other parts. This unhappy state of affairs prevails in spite of much data on these species as well as an almost endless array of hypotheses suggested for explaining the occurrence of regular cycles (for a review, see Stenseth, 1985a).

Most of the suggested hypotheses refer more or less explicity to 
Microtus species (see, e.g., Stenseth et al., 1977, Stenseth [ed.], 1985b); relatively few models have been advanced with a Clethrionomys species in mind. This may be unfortunate since the ecology and social behaviour of the genus Clethrionomys seem to be far more homogeneous than those of the genus Microtus (see Table 1 in Stenseth et al., 1987 for a comparison). Specifically, all Clethrionomys species seem to have females possessing exclusive territories (e.g., Bujalska, 1985) whereas few Microtus species seem to have this feature (e.g., Stenseth et al., 1987); but $M$. pennsylvanicus is, for example, like Clethrionomys in this respect (Boonstra \& Rodd, 1983).

Clethrionomys as a genus is, however, characterized by having both stable and cyclic populations (e.g., Henttonen et al., 1985) just as in the case of Microtus (e.g., Myllymäki et al., 1977; Stenseth et al., 1977, 1985). The bank vole, Clethrionomys glareolus, is of particular interest: North Scandinavian populations of this species are cyclic whereas south Scandinavian populations and central European ones are fairly stable from one year to another (e.g., Bujalska, 1970, 1983, 1985a, b; Myllymäki ct al., 1977; Stenseth et al., 1985; Henttonen et al., 1985). At most, there is a two year cycle with small amplitudes in the central European populations (e.g., Bujalska, 1975); in this case, it is the number of immature females which fluctuates regularly whereas the number of mature females seems rather constant.

Bujalska (1970, 1983), Bujalska et al. (1968) and Bujalska and Gliwicz (1972) proposed that the prevalence of exclusive female territories could explain the stability of the central European populations: once all territories are occupied, reproduction decreases so as to stabilize the population density. Wiger (1982) proposed - as far as we can see - that essentially the same mechanism (i.e., exclusive female territoriality) could explain the regular cycles in the more northern populations. That is, according to Wiger, the system of female territoriality sets a limit to the density of breeding females. This by itself, he says, will not necessarily produce cycles. However, the territoriality of females is the central feature of his hypothesis for explaining cyclic density changes.

This might seem like a paradox: to us it is not clear why Bujalska's suggestion should not also apply to the northern populations, nor why Wiger's suggestion should not also apply to the more southern populations. None of the two authors seem to address this question. In fact, we are unaware of any convincing arguments as to why the Bujalska suggestion should be an appropriate explanation for the stability of the central European bank vole populations, and why the Wiger-suggestion should be an appropriate explanation for the cyclicity of the northern population. Neither Bujalska nor Wiger give such arguments 
The purpose of this paper is therefore to attempt to specify the idea of Bujalska and Wiger about the population dynamics of Clethrionomys species. In particular, we evaluate whether their predictions are correct and hence whether female territoriality can explain both cyclicity in northern and non-cyclicity in southern populations. If so, the seeming conflict between the views of Bujalska and of Wiger is in reality nonexistent

\section{THEORY}

\subsection{The Basic Idea}

Reproductive females in all Clethrionomys species possess exclusive breeding territories (for review, see Bujalska, 1985b). As argued by Bondrup-Nielsen and Ims (1987) and Stenseth et al. (1987), this justifies disregarding the male component in population dynamics considerations: the dynamics of Clethrionomys populations may, presumably, be entirely understood by only considering females, since a sufficient number of mature males is always available for inseminating mature females in the population, and as a result, the males' population dynamics will passively "follow" the population dynamics of the females in a more or less complicated fashion.

The more competition there is for territories, the longer time is, on average, required before a female can start reproducing (Koshkina, 1957; Koshkina \& Korotkov, 1975; Viitala, 1977; Wiger, 1979, 1982): functionally subadult individuals (non-reproductive overwintered adults and young immatures) will, on average, have to "wait" for a longer time the higher the female density is before they become reproductively active adults. Similarly, mature individuals will produce litters less frequently at high densities, presumably because of mutual interactions between territorial females (Bujalska, 1983). Presumably, in dense populations the variation in the length of these "waiting-times" is greater than in sparse populations (Bondrup-Nielsen, pers. comm.; Ims, pers. comm.). However, in either case the lower realized value of this "waitingtime" is zero.

Naturalists are well aware of the marked seasonality in the reproductive schedule of small rodents (e.g., Formozov, 1964; Fuller, 1967; Pruitt, 1978): the main reproductive period occurs during summer. Even though seasonality and in particular the length of the main reproductive season were not emphasized as important factors by Bujalska nor by Wiger, we choose to interpret their writings as if they implicitly assumed so. At least Wiger (1982) mentions, referring to Fuller (1967), the fact that cyclic species seem to be associated with snowy winters 
(see also Fuller, 1985). Hence, we incorporate seasonality in our model; specifically we study the effect of long summers and short winters, as opposed to short summers and long winters. In the former case, more litters may be produced during the main reproductive period than in the latter case.

\subsection{The Model}

2.2.1. Definition of Variables

At any instant of time,

$N_{p}(i)$ is the number of pregnant females in their $i^{\text {th }}$ day of pregnancy ( $i=1,2, \ldots, 20$; see, e.g., Nanmov, 1948; Bujalska \& Ryszkowski, 1966). $N_{n p}(i)$ is the number of mature, but non-pregnant females which will become pregnant within $i$ days $(i=1,2, \ldots, 50$; see, e.g., Buchalczyk, 1970); the length of this period is (for simplicity) assumed predetermined by the level of aggression between territorial females.

$N_{s}(i)$ is the number of functionally subadult (see e.g., Myllymäki, 1977) females which will mature within $i$ days $(i=1,2, \ldots, 50$; see, e.g., Bujalska et al., 1968; Buchalczyk, 1970; Bujalska, 1983), again is assumed predetermined by the level of aggression between territorial females. These females may appropriately be called "maturing subadults" (or only "maturing"). All pregnant $\left(N_{p}\right)$, mature but non-pregnant $\left(N_{n p}\right)$, and maturing females $\left(N_{s}\right)$ occupy a territory (Gliwicz \& Rajska-Jurgiel, 1983). These are the only ones which defend their home ranges (Gliwicz \& Rajska-Jurgiel, 1983). Further, let $X$ be the number of nonterritorial females in the population at any instant in time. Subadults are recruited from this category. Non-territorial females are themselves recruited from newly weaned females. Finally, let $Y(i)$ be - at any instant in time - the total number of nestling females $i$ days old ( $i=$ $=1,2, \ldots, 20$; see Naumov, 1948; Bujalska \& Ryszkowski, 1966; Bujalska, 1983).

\subsubsection{Winter Dynamics}

During winter, lasting for $365-T_{s}$ days (where $T_{s}$ is the length of the summer season), the population is assumed to consist exclusively of non-territorial individuals. That is, during winter $X \geqslant 0$ and $N_{p}(i)=$ $=N_{n p}(i)=N_{s}(i)=Y(i)=0$ for all $i$.

Only death of non-territorial females (the entire female population at that time) can change the population density during winter. The instantaneous specific death rate of non-territorial females, $\mu_{w}$, is defined as

$$
\mu_{w}(X)=a_{1}+a_{2} \cdot X
$$


where $a_{1}$ and $a_{2}$ are two positive constants. Thas is, during the winter period

$$
X(t+1)=X(t) \cdot\left(1-\mu_{w} X(t)\right)
$$

We have assumed that only weaned individuals "survive" the transition from summer to winter.

\subsubsection{Summer Dynamics}

The dynamics and transitions between various categories of animals during summer are illustrated in Fig. 1.

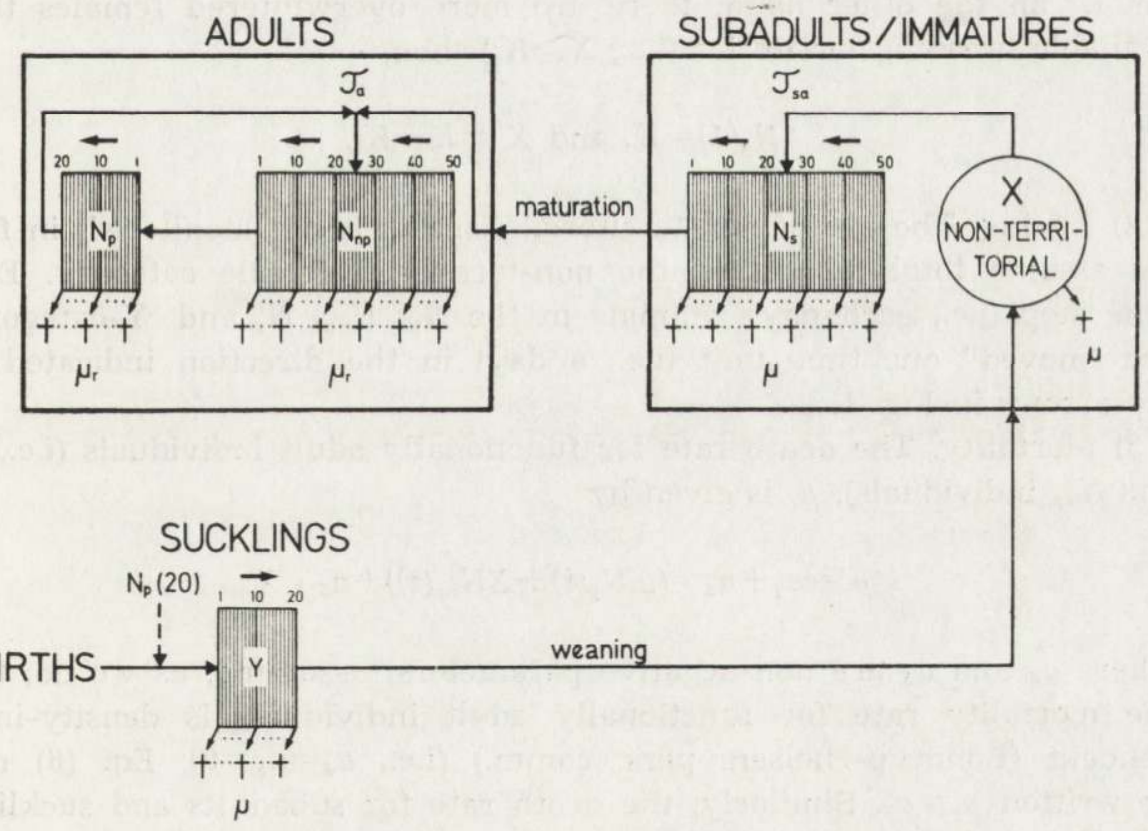

Fig. 1. Diagram showing the flow of individuals between various categories of the population. See main text for interpretation.

1) Initiation of reproductive season. All overwintered (immature and non-territorial) individuals will remain as non-territorial individuals only subjected to an instantaneous mortality rate given by Eq. (1) for a certain lag period, the length of which, $\tau_{w}$, is determined by the population density. We assume

$$
\tau_{w}=a_{3} \cdot X / K_{\mathrm{t}}
$$


where $K_{t}$ and $a_{3}$ are two positive parameters; $K_{t}$ determines the total number of territories in the habitat (i.e., its carrying capacity as measured in number of territories) and $a_{3}$ the length of the time lag when $X=K_{t}$. After $\tau_{w}$ days from the first potential day of summer overwintered females may become pregnant.

(i) If there are fewer overwintered females than available breeding territories in the habitat (i.e., $X \leqslant K_{t}$ ) then,

$$
N_{p}(1)=X \text { and } X^{\prime}=0
$$

where $X^{\prime}$ is the number of non-territorial individuals after the "transition" between animal categories has occurred.

(ii) If, on the other hand, there are more overwintered females than available breeding territories (i.e., $X>K_{t}$ ) then,

$$
N_{p}(1)=K_{t} \text { and } X^{\prime}=X-K_{t} \text {. }
$$

2) Ageing. The age of non-territorial females is not monitored; in fact, we assume total mixing of the non-territorial female category. Each time step (i.e., each day), animals in the $N_{p}, N_{n p}, N_{s}$ and Y-categories are "moved" one time unit (i.e., a day) in the direction indicated by the arrows in Fig. 1.

3) Mortality. The death rate for functionally adult individuals (i.e., $N_{p}$ and $N_{n p}$ individuals), $\mu_{r}$ is given by

$$
\mu_{r}=a_{1}+a_{4} \cdot\left(\Sigma N_{p}(i)+\Sigma N_{n p}(i)\right)+a_{5} \cdot X
$$

where $a_{4}$ and $a_{5}$ are non-negative parameters; assuming, as we do, that the mortality rate for functionally adult individuals is density-independent (Bondrup-Nielsen, pers. comm.) (i.e., $a_{4}=a_{5}=0$ ), Eq. (6) may be written $\mu_{r}=a_{1}$. Similarly, the death rate for subadults and sucklings ( $N_{s}, X$ and $Y$ individuals), $\mu$, is given by

$$
\mu=a_{1}+a_{6} \cdot\left(\Sigma N_{p}(i)+\Sigma N_{n p}(i)\right)+a_{2} \cdot X
$$

where $a_{6}$ is a non-negative parameter; assuming, as we do, that the mortality rate for subadults is density-dependent (Bondrup-Nielsen, pers. comm.) - and specifically assuming $a_{6}=0-$ Eq. (7) may be written $\mu=a_{1}+a_{2} X$ (see, Eq. (1)).

4) Reproduction. Litter size is assumed to be a fixed parameter in the model. That is, no density dependence is assumed for the reproductive output by those females having a breeding territory. This is supported 
by observations summarized by Bondrup-Nielsen and Ims (1987) and Bondrup-Nielsen (1985).

5) Maturation. Non-territorial females $(X)$ will be recruited to the adult population $\left(N_{p}\right.$ and $N_{n p}$ ) through the intermediate subadult or transition stage of maturating females $\left(N_{s}\right)$, given that there are breeding territories available (i.e., if $\Sigma N_{p}(i)+\Sigma N_{n p}(i)+\Sigma N_{s}(i)<K_{t}$ ). Individuals about to be recruited to the adult category will remain in the subadult category for a shorter or longer time period depending on current population density. Let this lag period be denoted $\tau_{s a}$; it is determined by using an auxiliary variable, $\tau_{1}$, defined by

$$
\tau_{1}=a_{3} \cdot\left(\Sigma N_{s}(i)+X\right) /\left(K_{t}-\Sigma N_{p}(i)-\Sigma N_{n p}(i)\right)
$$

where $a_{3}$ equals the length of the lag, or "waiting time", when the current number of subadult and non-territorial individuals is equal to the number of available territories without breeding females. Then

$$
\tau_{s a}=\left\{\begin{array}{cl}
a_{3} & \text { if } a_{3} \leqslant \tau_{1} \\
\tau_{1} & \text { if } 1<\tau_{1}<a_{3} \\
1 & \text { if } \tau_{1} \leqslant 1
\end{array}\right.
$$

That is, $a_{3}$ is the maximum length of "waiting".

6) Parturition-conception lag period. Recently maturated subadults and adult females recently having delivered a litter, will not become pregnant before a time, $\tau_{u}$, has elapsed. Let an auxiliary variable $\tau_{2}$ be defined by

$$
\tau_{2}=a_{3} \cdot\left(\Sigma N_{p}(i)+\Sigma N_{n p}(i)\right) / K_{t}
$$

where $a_{3}$ is now interpreted as the time required for a female which has just delivered a litter to become pregnant again, when the total density of breeding females equals the total number of territories available. Then, $\tau_{a}$ is defined by

$$
\tau_{a}=\left\{\begin{array}{cl}
1 & \text { if } \tau_{2} \leqslant 1 \\
\tau_{2} & \text { if } 1<\tau_{2}<50 \\
50 & \text { if } 50 \leqslant \tau_{2} .
\end{array}\right.
$$

The number 50 have been extracted from Buchalczyk (1970) and Bujalska (1983).

$$
\text { 2.2.4. Summary of the Model }
$$

In short, the important features that we include in our analysis are: 
(i) The populations dynamics as a whole are assumed to be governed solely by the populations dynamics of females.

(ii) During winter, the female population is socially unstructured all females are non-territorial.

(iii) During summer, the female population is socially structured with respect to age. A female passes through five consecutive stages: i.e., suckling $\rightarrow$ immature $\rightarrow$ subadult $\rightarrow$ non-pregnant adult $\rightarrow$ pregnant adult, where the three last stages are territorial.

(iv) The time spent as immature, subadult and non-pregnant adult increases with increasing population density.

(v) Mortality rates of non-territorial stages increase with total population density of non-territorial individuals; mortality rates of territorial stages are independent of density.

Hence, we assume density dependent negative feed-black in the reproductive performance of females: high density implies a low specific rate of reproduction (due to a long waiting time before becoming pregnant) and vice versa. Our problem now, is to see whether this feature is sufficient to generate persistent cycles, and, in particular, whether the maximum length of the reproductive season is important.

The model has been studied by numerical analysis (a FORTRAN program defining the model precisely may be obtained from the senior author). A standard set of parameters has been used (Table 1); the population dynamical effects of varying one of these, or a combination of these, have been studied and are reported below.

Table 1

Parameter - and parameter values - used in the model; in all of our analyses we have assumed $a_{4}=a_{5}=a_{6}=0$ (i.e., no density-dependence in survival rates for adult female categories).

\begin{tabular}{|c|c|c|}
\hline Parameter & $\begin{array}{l}\text { Parameter values } \\
\text { used }\end{array}$ & Definition \\
\hline$K_{t}$ & $100 \& 1000$ & $\begin{array}{l}\text { Carrying capacity }=\text { number of breeding } \\
\text { territories. }\end{array}$ \\
\hline$a_{3}$ & $1,20,30 \& 40$ & $\begin{array}{l}\text { Extent of reproductive lag (at the start } \\
\text { of the season and between litters). }\end{array}$ \\
\hline B & $1,3 \& 5$ & $\begin{array}{l}\text { Litter size (only females) for reproductively } \\
\text { active females. }\end{array}$ \\
\hline $\begin{array}{l}a_{1} \\
T_{s}\end{array}$ & $\begin{array}{l}0.001 \& 0.0001 \\
60,120 \& 160\end{array}$ & $\begin{array}{l}\text { Density independent daily mortality rate. } \\
\text { Length of the potential main summer } \\
\text { breeding season (in days). }\end{array}$ \\
\hline
\end{tabular}

Throughout, we evaluate which parameter combinations tend to destabilize the population dynamics. 


\section{RESULTS}

We have analyzed the effects of varying the number of possible territories in a particular region $\left(K_{t}\right.$; determined by the primary productivity of the region), the maximum length of time between litter delivery and the next successful mating when all territories are occupied $\left(a_{3}\right)$, the litter size $(B)$, the maximum length of the summer period $\left(T_{s}\right)$, and the density independent mortality rate $\left(a_{1}\right)$; see Table 1 .

In general, we find that most parameter combinations result in a fairly stable population dynamics. Changing the primary productivity of the region (i.e., $K_{t}$ ) seems to have no effect on the population dy-

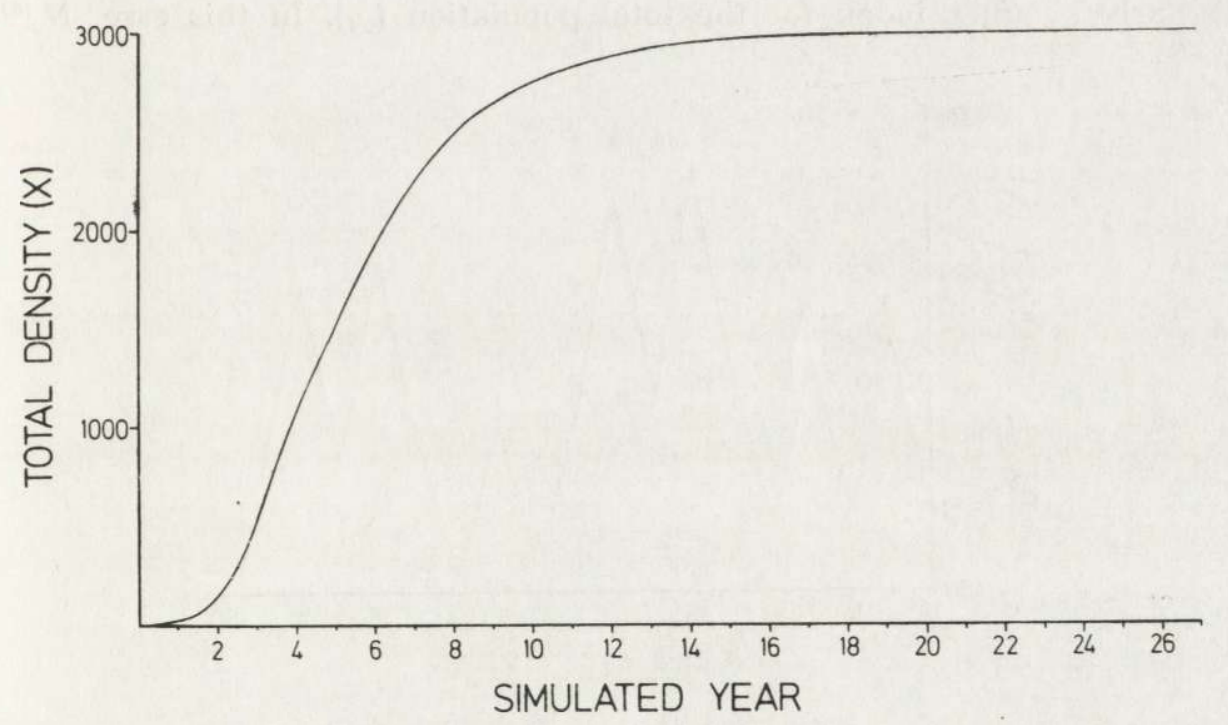

Fig. 2. Population dynamic pattern for a typical stable population. Parameter values used are: $K_{t}=1000, a_{3}=40, B=1, a_{1}=0.001$ and $T_{s}=120$.

namics. This certainly is consistent with the results obtained by analyzing a somewhat different model (disregarding seasonality) for the same general Clethrionomys type of biology (Stenseth et al., 1987). The exclusive territoriality of Clethrionomys females seems in most cases to lead to a stable population dynamics.

We have, however, found that seasonality, particularly when combined with high reproductive intensity, may produce density fluctuations (see Table 2). More precisely, increasing litter size or decreasing the potential length of the main breeding season may destabilize the population dynamics if $a_{3}$, the extent of time lag due to aggressivity between territorial females, is larger than one; if $a_{3}=1$, the population 
dynamics are - as should be expected - very stable. Some typical patterns of population dynamics resulting from the model are depicted in Figs. 2-4.

In Table 3 we have summarized the results of our analysis by calculating the cyclicity index (Stenseth, 1977; Stenseth \& Framstad, 1980), $\varrho$, defined by

$$
\varrho=\left[\operatorname{var}\left(\log _{10} N_{y}{ }^{(d)}\right)\right]^{1 / 2}
$$

where $N_{y}{ }^{(d)}$ is the total density of the population in the $d^{\text {th }}$ day of year $y$, and the variance is taken between years (at day $d$ ); we have calculated four different $\varrho$-indices referring to different times of the year (i.e., different $d$-values) and/or different segments of the population: 1) Early summer index for the total population $\left(\varrho_{1}\right)$. In this case, $N_{y}{ }^{(d)}$

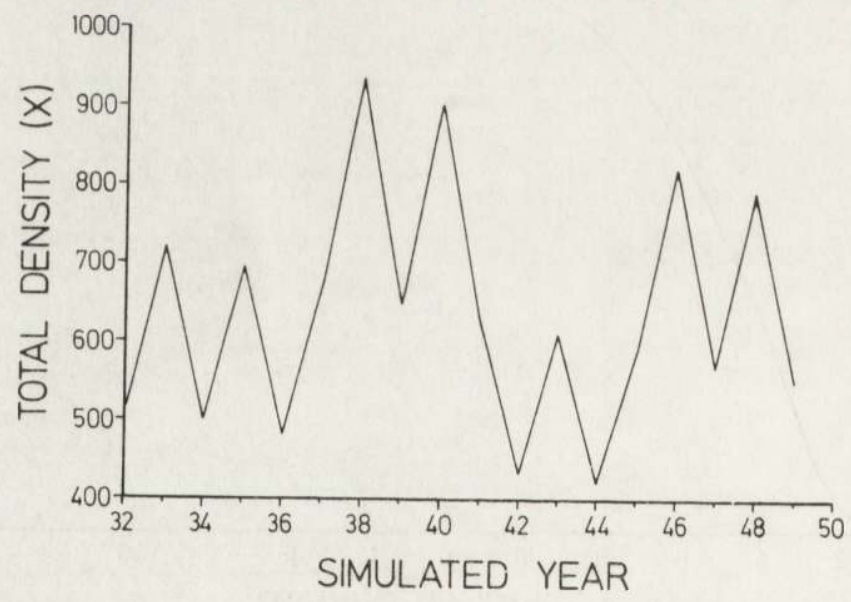

Fig. 3. Population dynamic pattern for fluctuating population. Parameter values used are: $K_{t}=1000, a_{3}=40, B=1, a_{1}=0.001$ and $T_{s}=60$.

Table 2

Stability properties of the model for various combinations of parameter values. Numbers give the percentages which - over all parameter combinations (see Table 1) - give density fluctuations.

\begin{tabular}{lllllllll}
\hline & \multicolumn{3}{c}{$B$} & & & \multicolumn{3}{c}{$T_{s}$} \\
\cline { 2 - 3 } \cline { 5 - 7 } & 1 & 3 & 5 & & 60 & 120 & 180 \\
\hline $\begin{array}{l}\text { Percentage cases with } \\
\text { fluctuating populations }\end{array}$ & 27 & 36 & 36 & & 100 & 0 & 0 \\
\hline
\end{tabular}


is defined as the total population five days after the "initiation of the reproductive season" has started. For that day we calculate

$$
N_{y}^{(d)}=\Sigma N_{p}(i)+\Sigma N_{n p}(i)+\Sigma N_{s}(i)+X
$$

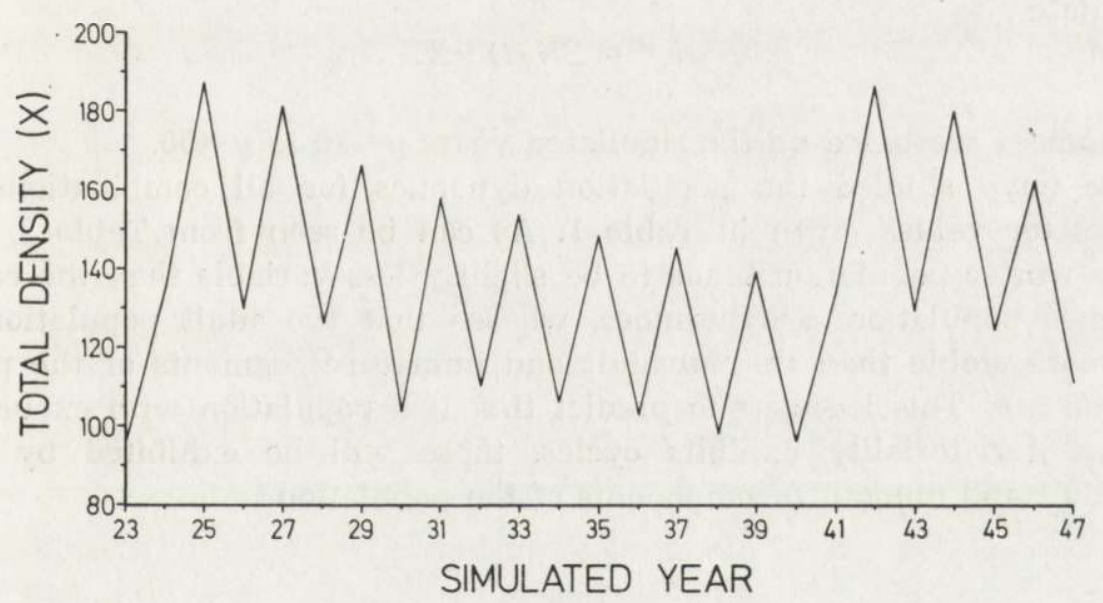

Fig. 4. Population dynamics pattern for a fluctuating population. Parameter values used are: $K_{t}=1000, a_{3}=20, B=1, a_{1}=0.001$ and $T_{s}=60$.

2) Early winter index for the total population $\left(\varrho_{2}\right)$. In this case, $N_{y}{ }^{(d)}$ is defined by (13) but on the fifth day after the termination of the summer. In this case, $N_{y}^{(d)}=X$ since $N_{p}(i)=N_{n p}(i)=N_{s}(i)=0$ for all i at this time of the year.

\section{Table 3}

Summary of the values of the cyclicity-indices $\left(\varrho_{1}, \varrho_{2}\right.$, $\varrho_{3}$ and $\left.\varrho_{4}\right)$ obtained for all possible combinations of parameter values shown in Table 1 .

\begin{tabular}{lcccc}
\hline Index & $\begin{array}{c}\text { Mean } \\
\text { value }\end{array}$ & $\begin{array}{c}\text { Coefficient } \\
\text { of variation }\end{array}$ & $\begin{array}{c}\text { Minimum } \\
\text { value }\end{array}$ & $\begin{array}{c}\text { Maximum } \\
\text { value }\end{array}$ \\
\hline$\varrho_{1}$ & 0.044 & 0.73 & 0.0031 & 0.14 \\
$\varrho_{2}$ & 0.042 & 0.74 & 0.0025 & 0.14 \\
$\varrho_{3}{ }_{1}$ & 0 & 0.52 & 0 & 0 \\
$\varrho_{4}$ & 0.045 & 0.91 & 0.0026 & 0.21 \\
\hline
\end{tabular}

1 The $\rho_{3}$-values are all very small and may, for all practical purposes, be considered equal to zero; i.e., corresponding to a stable population.

3) Late summer index for adult females only $\left(\varrho_{3}\right)$. In this case, $N_{y}{ }^{(d)}$ is defined as the total number of adult, reproductively active, females ten days before the termination of the summer. For that day we calculate 


$$
N_{y}^{(d)}=\Sigma N_{p}(i)+\Sigma N_{n p}(i) .
$$

4) Late summer index for subadult and immature females only $\left(\varrho_{4}\right)$. In this case, $N_{y}{ }^{(d)}$ is defined as the total number of subadults and immatures ten days before the termination of the summer. For that day we calculate

$$
N_{y}^{(d)}=\Sigma N_{s}(i)+X
$$

All indices are based on the simulated years $y=20$ to $y=50$.

We have studied the population dynamics for all combinations of parameter values given in Table 1 . As can be seen from Table 3 , the early winter population tends to be slightly less variable than the early summer population. Furthermore, we see that the adult population is far more stable than the subadult and immature segments of the population are. This leads us to predict that if a population with exclusive female territoriality exhibits cycles, these will be exhibited by the subadult and immature components of the population.

Table 4

Multiple correlation analysis showing the relation between the cyclicity indices and the various parameters studied (see Table 1). The analysis was done with $K_{t}, a_{1}, B, a_{3}$ and $T_{s}$ as independent variables and $\varrho$ as the dependent variable; however, $\mathrm{a}_{3}$ and $\mathrm{B}$ were never found to be significantly correlated with any of the cyclicity-indices. Minus means significant negative correlation; plus means significant positive correlation. Three symbols mean significant at the 0.001 level, two symbols mean significant at the 0.01 level, and one symbol means significant at the 0.05 level. A symbol in parentheses means almost significant at that level. A zero means no significant relation.

\begin{tabular}{cccc}
\hline$\varrho_{1}$ & $\mathrm{~K}_{\mathrm{t}}$ & $\mathrm{a}_{1}$ & $\mathrm{~T}_{\mathrm{s}}$ \\
\hline 1 & $(+)$ & --- & --- \\
2 & $(+)$ & $-\frac{-}{0}$ & $-\frac{0}{0}$ \\
3 & +++ & - & -- \\
4 & 0 & --- & -
\end{tabular}

We have further correlated the values of each of these four indices to the values of the parameter values used in our analysis (Table 1): the results are summarized in Table 4 . As can be seen, increased density-independent mortality rate $\left(a_{1}\right)$ stabilizes the population dynamics significantly. Similarly, increased length of the main breeding season $\left(T_{s}\right)$ also stabilizes the population dynamics significantly. Finally, there is a tendency for increasing the degree of cyclicity in areas with high values of $K_{t}$ (i.e., in more productive areas). Notice, however, that $K_{t}$ has no effect on the density of the total population; this is consistent with the quality analysis reported above. 
It should be noticed that we do not see any effect of litter size in this analysis (Tab. 4), in contrast to the effect seen in Table 2. Presumably this is due to the fact (indicated by Tab. 2) that this effect is so much weaker than the effect of survival and length of main reproductive period that it does not show up in our correlation analysis. It should also be realized that the stability measure used in Table 2 is qualitative whereas that used in Table 4 is quantitative (i.e., Eq. (12)). The amplitude is only of importance in the latter case. Hence, it may be arqued that our analysis suggests that increasing values of $B$ certainly destabilize the population dynamics, but so that the amplitude of the resulting fluctuation is only slightly affected (hence, changing $B$ has only a slight effect on the $\varrho$-value).

An interesting feature of our model is that a non-synchronized reproduction occurs in areas with low realized densities compared to the carrying capacity of the region. In areas where the realized density is fairly close to the carrying capacity of the region, a synchronous reproduction emerges; i.e., litters are produced synchronously at regular intervals. Hence, it seems reasonable to apply the concept of a cohort structure only to populations which are fairly close to their carrying capacity. Presumably, we would not have obtained this result if we, in the model, had incorporated a stochastically varying "waiting time".

\section{DISCUSSION}

It is fairly easy to understand why we obtain the results we do: a lag in initiating reproduction in the spring and a lag between litter productions may easily cause fluctuations in regions with short summers since then one or two "potential" cohorts (sensu Gliwicz et al., 1968) out of a few cohorts are "lost". In regions with long summers, however, the relative number of cohorts "lost" will be fairly small. Therefore, the density-dependent effects introduced by the reproductive lag become more pronounced in regions with short summers than in regions with long summers: essentially then, our result is a special case of a more general result in population dynamic theory saying that too strong density dependence in a seasonal environment (i.e., discrete breeding) may cause fluctuations (e.g., Maynard Smith, 1968; see also Stenseth \& Antonsen, 1987a, b).

Another feature of our model is also consistent with general population dynamics theory: the positive correlation between the degree of cyclicity and the carrying capacity $\left(K_{t}\right)$ corresponds directly to "the paradox of enrichment" (Rosenzweig, 1971; see also May, 1972, 1981).

It is important to realize that the extent of time lag $\left(a_{3}\right)$ in itself did 
not affect the stability of the population (see legend to Table 4). Hence, our result is contrary to what should be expected on the basis of Hutchinson's (1948) analysis. The differences in his and our results are, of course, due to our model being far more detail-rich than Hutchinson's model. (See Stenseth, 1984: 263-264, for a general discussion of time lag models as applied to microtine rodent populations.)

Analysis of the model suggests that populations with exclusive female territoriality may exhibit variation in the subadult (or immature) fraction of the population. This theoretical result seems, in fact, to reflect what is observed in natural Clethrionomys populations: For example, Bujalska (1970) observed for a population of C. glareolus a stable density of mature females but a two-year cycle in the density of subadult and immature females. Similarly, Koshkina and Korotkov (1975) found for a population of C. rutilus a stable density of mature females but a varying density of subadults and immature in the optimal habitats. A similar pattern was observed by Fuller (1985) for C. rutilus and $C$. gapperi. We are confident that this list supporting our model-prediction may be greatly expanded.

Although we have thus been able to generate cyclicity in a qualitative sense, we have not demonstrated a satisfactory quantitative agreement with real microtine cycles. This is not to say that such an agreement could not, in principle, be found with the present model. Our reasons for not pursuing the analysis beyond the qualitative stage are, first, that Bujalska's and Wiger's hypotheses are qualitative, and second, that one immediately runs into interpretational problems if the system is to be quantified. For example, no real population lives in an environment devoid of predators, nor are there any real populations that live in an environment with a constant carrying capacity. These, and other, factors may very well be involved in determining the exact pattern of the cycles, once cyclicity itself is generated by internal mechanisms in the vole population.

In this connection it is worth while to point out that none of the cyclicity indices used in our analysis (Tab. 3) have values as high as those found by Henttonen et al. (1985) for a variety of Clethrionomys populations. In fact, Henttonen et al. (1985) suggested that a cyclicity index (i.e., $\varrho_{2}$ ) below 0.5 should be considered to correspond to a stable population whereas a cyclicity index above 0.5 should be considered correspond to a cyclic population. We are confident that the consistently low values of all our cyclicity indices are due to the fact that we purposely have disregarded environmental factors such as predation and food availability.

It is, however, rather interesting to observe that the same mechanism 
(i.e., female territoriality) may lead to stability as well as to instability of population density depending on the values of easily interpretable parameters in the model (length of the summer and litter size).

With regard to Bujalska's and Wiger's hypotheses, we therefore suggest that exclusive female territoriality is not sufficient to explain neither the stability of southern populations (as suggested by Bujalska), nor the cyclicity of northern ones (as suggested by Wiger). We cannot say whether female territoriality is necessary to produce either type of population dynamics, since we have not attempted to relax the assumption of territoriality; all we can say is, in very general terms, that our model (which includes territoriality) is stable over very large parts of parameter space, but that it is destabilized by factors such as short summers and low specific mortality rates.

Clearly then, it is safe to conclude that female territoriality certainly is consistent with either type of population dynamics found by $\mathrm{Bu}$ jalska and by Wiger: if the potential reproductive period is short, density fluctuations will result. Otherwise, the population tends to be stable. This seems to be supported by observations: regular density cycles seem only to be observed in areas with long (snowy) winters (e.g., Fuller, 1967; see also Henttonen \& Hansson, 1985a).

In addition we have found a tendency for increasing litter size per reproductively active female to destabilize the population dynamics. Our results therefore suggest that the commonly observed positive correlation between degree of density variation on cyclicity and litter size (e.g., Stenseth \& Framstad, 1980; Stenseth et al., 1985b; but see Henttonen \& Hansson, 1985b; Hansson \& Henttonen, 1985) is actually a causal relationship: increased litter size causes increased cyclicity.

Our overall conclusions, then, are these: Both the hypothesis proposed by Bujalska (1970) for explaining the stability of the central European Clethrionomys glareolus populations, and the hypothesis proposed by Wiger (1982) for explaining the cyclicity of the north European C. glareolus populations are plausible, but incomplete. We presume that both authors were implicitly referring to different parts of the parameter space. Then, there is not necessarily any paradox: the same biological mechanisms may explain both types of population dynamics depending on the parameter combinations, although additional factors, such as predator-prey interactions (e.g., Pearson, 1966, 1971), may be required to approach a refined quantitative understanding. Wiger (1982) did in fact suggest the importance of such additional factors. We have demonstrated the importance of his suggestion. 
Acknowledgements: Financial support was received from the Nordic Council of Ecology (NKE), the Swedish National Science Foundation (NFR), and each of our two home institutions. Fred Roger Horndal is thanked for splendid technical assistance when carrying out the final analysis. Søren Bondrup-Nielsen, Gabriela Bujalska and Joanna Gliwicz are further thanked for offering valuable comments on the ideas presented in this paper.

\section{REFERENCES}

1. Bondrup-Nielsen S., 1985: An evaluation of the effects of space use and habitat patterns on dispersal in small mammals. Ann. Zool. Fennici, 22: 373$-383$.

2. Bondrup-Nielsen S. \& Ims R. A., 1987: Predicting stable and cyclic populations of Clethrionomys. Oikos (in press).

3. Boonstra R. \& Rodd F. H., 1983: Regulation of breeding density in Microtus pennsylvanicus. J. Anim. Ecol., 52: 757-780.

4. Buchalczyk A., 1970: Reproduction, mortality and longevity of the bank vole under laboratory conditions. Acta theriol., 15: 153-176.

5. Bujalska G., 1970: Reproduction stabilizing elements in an island population of Clethrionomys glareolus (Schreber, 1780). Acta theriol., 15: 381-412.

6. Bujalska G., 1975: Reproduction and mortality of bank vole and the changes in the size of island population. Acta theriol., 20: 41-56.

7. Bujalska G., 1983: Reproduction. [In: "Ecology of the bank vole", Ed. K. Petrusewicz]. Acta theriol., 28, Suppl. 1: 148-161.

8. Bujalska G., 1985a: Fluctuations in an island bank vole population in the light of the study on its organization. Acta theriol., 30: 3-49.

9. Bujalska G., 1985b: Regulation of female maturation in Clethrionomys species with special reference to an island population of C. glareolus. Ann. Zool. Fennici, 22: $331-342$.

10. Bujalska G. \& Ryszkowski L., 1966: Estimation of the reproduction of the bank vole under field conditions. Acta theriol., 11: 351-361.

11. Bujalska G. \& Gliwicz J., 1972: Growth and reproduction of female bank voles under field conditions. Acta theriol., 17: $33-40$.

12. Bujalska G., Andrzejewski R. \& Petrusewicz K., 1968: Productivity investigation of an island population of Clethrionomys glareolus (Schreber, 1780). II. Natality. Acta theriol., 13: 415-425.

13. Elton C., 1942: Voles, mice and lemmings. Oxford Univ. Press: Oxford.

14. Formozov A. N., 1964: Snow cover as an integral factor of the environment and its importance in the ecology of mammals and birds. Occ. Publ. No. 1 Boreal Inst., University of Alberta.

15. Fuller W. A., 1967: Ecologie hivernale des lemmings et fluctuations de leurs populations. Terre Vie, 2: 97-115.

16. Fuller W. A., 1985: Demography of Clethrionomys gapperi, parapatric C. rutilus and sympatric Peromyscus maniculatus in northern Canada. Ann. Zool. Fennici, 22: 229-241.

17. Gliwicz J. \& Rajska-Jurgiel E., 1983: Social organization. [In: "The ecology of the bank vole", Ed. K. Petrusewicz.] Acta theriol., 28 Suppl. 1: 134-141.

18. Gliwicz J., Andrzejewski R., Bujalska G. \& Petrusewicz K., 1968: Productivity investigation of an island population of Clethrionomys glareolus (Schreber, 1780). I. Dynamics of cohorts. Acta theriol., 13: 401-413.

19. Hansson L. \& Henttonen H., 1985: Regional differences in cyclicity and re- 
production in Clethrionomys species: are they related? Ann. Zool. Fennici, 22: $277-288$.

20. Henttonen H. \& Hansson L., 1985a: Gradients in density variations of small rodents: the importance of latitude and snow cover. Oecologia, 67: $394-402$.

21. Henttonen H. \& Hansson L., 1985b: Litter size related to cyclicity or environmental conditions - a reexamination of data from the vole Clethrionomys rutilus. Can. J. Zool., (in press).

22. Henttonen H., McGuire A. D. \& Hansson L., 1985: Comparisons of amplitudes and spectral analysis of density variations in long term data sets of Clethrionomys species. Ann. Zool. Fennici, 22: 221-227.

23. Hutchinson G. R., 1948: Circular causal system in ecology, Ann. N. Y. Acad. Sci., 50: $221-246$.

24. Koshkina T. V., 1957: Comparative ecology of red backed voles in northern taiga. Materials About Rodents, Fauna and Ecology of Rodents, 5: 3-65 (Moscow Soc. Naturalist, Eng. trans. in Boreal Inst., Univ of Alberta).

25. Koshkina T. V. \& Korotkov Yu. S., 1975: Regulative adaptations in populations of red vole (Clethrionomys rutilus) under optimum conditions of its range. F'auna and Ecology of Rodents, 12: 5-61 (Moscow Soc. Naturalists, Eng. trans. in Boreal Inst., Univ. of Alberta).

26. Krebs C. J., 1978: A review of the Chitty hypothesis of population regulation. Can. J. Zool., 56: 2464-2480.

27. Krebs C. J., 1979: Dispersal spacing behaviour and genetics in relation to population fluctuations in the vole Microtus townsendii. Fortschr. Zool., 25: 61-77.

28. Krebs C. J. \& Myers J. H., 1974: Population cycles in small mammals. Adv. Ecol. Res., 8: 267-399.

29. May R. M., 1972: Limit cycles in predator-prey communities. Science, 177: $900-902$.

30. May R. M., 1981: Models for two interacting populations. [In: "Theoretical ecology", Ed. R. M. May], Sinauer Assoc. Inc. Publ: Sunderland, Mass.

31. Maynard Smith J., 1968: Mathematical ideas in biology. Cambridge Univ. Press: Cambridge.

32. Myllymäki A., 1977: Demographic mechanisms in fluctuating populations of the field vole Microtus agrestis. Oikos, 29: 468-493.

33. Myllymäki A., Christiansen E. \& Hansson L., 1977: Five-year surveillance of small mammal abundance in Scandinavia. EPPO Bull., 7: 385—396.

34. Naumov N. P. 1948: (Cited from Bujalska 1983).

35. Pearson O. P. 1966: The prey of carnivores during one cycle of mouse abundance. J. Anim. Ecol., 35: 217-233.

36. Pearson O. P. 1971: Additional measurements of the impact of carnivores on California vole (Microtus californicus). J. Mammal., 52: 41-69.

37. Pruitt W. D., Jr. 1978: Boreal Ecology. Edward Arnold: London.

38. Rosenzweig M. L. 1971: Paradox of enrichment: destabilization of exploitation ecosystems in ecological time. Science, 171: 385-387.

39. Stenseth N. C., 1977: Theoretical studies on fluctuating populations: an evolutionary approach. Unpubl. Doctoral Thesis, Univ. of Oslo.

40. Stenseth N. C., 1984: Why mathematical models in evolutionary ecology. [In: "Trends in Ecological Research for the 1980s." (Eds.) J. H. Colley \& F. B. Golley], Plenum Publ. Coop.

41. Stenseth N. C., 1985a: Mathematical models of microtine cycles: models and the real world. Acta Zool. Fenn. 171: 7-12. 
42. Stenseth N. C., (Ed.) 1985b: Population dynamics, reproduction and sociobiology in the genus Clethrionomys. Ann. Zool. Fenn., 22: 205-395.

43. Stenseth N. C. \& Antonsen B., 1987a: Density dependence and the microtine cycle (I): A continuous time model with delay due to development. Oikos (in press).

44. Stenseth N. C. \& Aotonsen B., 1987b: Density dependence and the microtine cycle (II): A discrete time model for a synchronously reproducing population. Oikos (in press).

45. Stenseth N. C. \& Framstad E., 1980: Reproductive effort and optimal reproductive rates in small rodents. Oikos, 34: $23-34$.

46. Stenseth N. C., Gustafsson T. O., Hansson L. \& Ugland K. I. 1986: On the evolution of reproductive rates in microtine rodents. Ecology, 66: 1795-1805.

47. Stenseth N. C., Bondrup-Nielsen, S. \& Ims R. A., 1987: A population dy namics model for Clethrionomys: sexual maturation, spacing behaviour and dispersal. Oikos (in press).

48. Stenseth N. C., Hansson L., Myllymäki A., Andersson M. \& Katila J., 1977: General models for the population dynamics of the field vole Microtus agrestis in central Scandinavia. Oikos, 29: 616-642.

49. Viitala J., 1977: Social organization in cyclic subarctic populations of the voles Clethrionomys rufocanus (Sund.) and Microtus agrestis (L.). Ann. Zool. Fennici, 14: $53-93$.

50. Wiger R., 1979: Demography of a cyclic population of the bank vole, Clethrionomys glareolus. Oikos, 33: 373-385.

51. Wiger R., 1982: Roles of self regulatory mechanisms in cyclic populations of Clethrionomys with special reference to C. glareolus: a hypothesis. Oikos, 38: 60-71.

Accepted, February 12, 1986.

\section{Nils Christian STENSETH i Torbjörn FAGERSTROM}

\section{REGULACJA ZAGESZCZENIA POPULACJI U CLETHRIONOMYS: WPEYW ZMIAN W WIELKOSCI MIOTU I DEUGOSCI SEZONU ROZRODCZEGO}

\section{Streszczenie}

Analizowany jest model stworzony dla badania skutków terytorializmu samic w dynamice populacji. Sprawdzono wiarygodność hipotezy Bujalskiej (1970), wyjaśniającej stabilność populacji C. glareolus w centralnej Europie, oraz istotę hipotezy Wigera (1982), tłumaczącej cykliczność północnych populacji tego gatunku. W pracy dowodzi się, że obie hipotezy są $\mathrm{w}$ istocie swej tożsame $\mathrm{w}$ sensie reprezentowania jednakowej teorii, lecz odniesionej do innych parametrów przestrzeni geograficznej. Na terenach $\mathrm{z}$ długim latem i stosunkowo małymi miotami wylączny terytorializm zawsze stabilizuje liczebność populacji (poparcie hipotezy Bujalskiej). Tymczasem na terenach o krótkim lecie i stosunkowo dużych miotach, terytorializm samic powoduje niestałą, cykliczną dynamikę liczebności populacji (konieczny warunek wiarygodności hipotezy Wigera). Nie byliśmy jednak w stanie zasymulować typowych cykli norników: wyraźnie konieczny jest dodatkowy czynnik, aby upodobnic cykle stworzone w niniejszym modelu do tych, jakie zachodza w rzeczywistej populacji. 